\title{
Quantitative Structure-Cytotoxicity Relationship of Newly Synthesized Piperic Acid Esters
}

\author{
HIROSHI SAKAGAMI ${ }^{1}$, YOSHIHIRO UESAWA ${ }^{2}$, YOSHIKO MASUDA ${ }^{1,3}$, MINEKO TOMOMURA $^{1,4}$, \\ SATOSHI YOKOSE ${ }^{3}$, TAKAKI MIYASHIRO ${ }^{5}$, JUNICHI MURAI ${ }^{5}$, KOICHI TAKAO $^{5}$, TAISEI KANAMOTO ${ }^{6,7}$, \\ SHIGEMI TERAKUBO ${ }^{7}$, HAJIME KAGAYA ${ }^{2}$, HIDEKI NAKASHIMA ${ }^{7}$ and YOSHIAKI SUGITA ${ }^{5}$ \\ ${ }^{1}$ Meikai University Research Institute of Odontology (M-RIO), Divisions of ${ }^{3}$ Endodontics and \\ ${ }^{4}$ Biochemistry, Meikai University, School of Dentistry, Saitama, Japan; \\ ${ }^{2}$ Department of Clinical Pharmaceutics, Meiji Pharmaceutical University, Tokyo, Japan; \\ ${ }^{5}$ Department of Pharmaceutical Sciences, \\ Faculty of Pharmacy and Pharmaceutical Sciences, Josai University, Saitama, Japan; \\ ${ }^{6}$ Laboratory of Microbiology, Division of Pharmaceutical Biology, Showa Pharmaceutical University, Tokyo, Japan; \\ ${ }^{7}$ Department of Microbiology, St. Marianna University School of Medicine, Kanagawa, Japan
}

\begin{abstract}
Background/Aim: Eleven piperic acid esters were subjected to quantitative structure-activity relationship (QSAR) analysis based on their cytotoxicity and tumorspecificity, in order to find their new biological activities. Materials and Methods: Cytotoxicity against four human oral squamous cell carcinoma cell lines and three oral normal mesenchymal cells was determined by the 3-(4,5dimethylthiazol-2-yl)-2,5-diphenyltetrazolium bromide (MTT) method. Tumor specificity (TS) was evaluated by the ratio of the mean $50 \%$ cytotoxic concentration $\left(C C_{50}\right)$ against normal cells to that against tumor cell lines. Potency-selectivity expression (PSE) value was calculated by dividing the TS value by $C_{50}$ against tumor cells. Apoptosis markers were detected by western blot analysis. Physicochemical, structural and quantum-chemical parameters were calculated based on the conformations optimized by force-field minimization. Results: One phenylmethyl ester and five phenylethyl esters showed relatively higher cytotoxicity and tumor specificity, that were significantly modified by introduction of hydroxyl and methoxy groups. On the other hand, phenylpropyl ester, phenylbutyl ester and decyl ester were essentially inactive.
\end{abstract}

This article is freely accessible online.

Correspondence to: Hiroshi Sakagami, Meikai University Research Institute of Odontology (M-RIO), 1-1 Keyakidai, Sakado, Saitama 3500283, Japan. Tel: +81-492792758 (office), +81 492792787 (M-RIO) (dial-in), Fax: +81 492855171, e-mail: sakagami@dent.meikai.ac.jp

Key Words: Piperic acid esters, QSAR analysis, cytotoxicity, tumor selectivity, apoptosis induction, anti-HIV activity.
(2E,4E)-5-(3,4-methylenedioxyphenyl)-2,4-pentadienoic acid 2-(3,4-dihydroxyphenyl)ethyl ester [4] had the highest TS and PSE values. This compound also stimulated the cleavage of caspase-3, suggesting the induction of apoptosis. TS values were correlated with molecular size, ionization potential, molecular shape, ionization potential and electronegativity. None of the compounds had any antiHIV activity. Conclusion: Chemical modification of the lead compound may be a potential choice for designing a new type of anticancer drugs.

Piperine \{1-[5-(1,3-benzodioxol-5-yl)-1-oxo-2,4-pentadienyl] piperidine)\}, along with its isomer chavicine, is a pungent alkaloid contained in black pepper (1). Piperine has been reported to enhance the oral absorption and hence the bioavailability of accompanying compounds $(2,3)$ and some antibacterial activity $(4,5)$. In animal studies, piperine showed anti-depression/cognitive-enhancing (6), antiinflammatory (7) and anti-angiogenic (8) activities.

Piperine induced apoptotic cell death in human colon cells (9), melanoma cells (10), and lung (11) and rectal carcinoma cell lines (12), whereas it induced autophagy in human prostate cancer cells (13). On the other hand, piperine protected normal cells from apoptosis induced by cadmium (14), cisplatin (15) and glutamate (16). However, as far as we know only one article has performed the rigorous antitumor investigation with appropriate normal cells from the same tissues or same type of cells (epithelial or mesenchymal) (11). Furthermore, there is no report about the antiviral activity of piperine. We have recently reported that among a total of 12 synthetic piperic acid amides, $N$-piperoyldopamine showed the highest tumor selectivity (17). 
In continuation of discovering new biological activities of piperine derivatives, a total of 11 synthetic piperic acid esters were investigated for their cytotoxicity and anti-HIV activity, and then subjected to quantitative structure-activity relationship (QSAR) analysis.

\section{Materials and Methods}

Materials. The following chemicals and reagents were obtained from the indicated companies: Dulbecco's modified Eagle's medium (DMEM), from GIBCO BRL, Grand Island, NY, USA; fetal bovine serum (FBS), 3-(4,5-dimethylthiazol-2-yl)-2,5-diphenyltetrazolium bromide (MTT), doxorubicin, azidothymidine, 2',3'-dideoxycytidine from Sigma-Aldrich Inc., St. Louis, MO, USA; dimethyl sulfoxide (DMSO), dextran sulfate (molecular mass, $5 \mathrm{kDa}$ ) from Wako Pure Chem. Ind., Osaka, Japan; methotrexate from Nacalai Tesque, Inc., Kyoto, Japan; curdlan sulfate (molecular mass, $79 \mathrm{kDa}$ ) from Ajinomoto Co. Ltd., Tokyo, Japan. Culture plastic dishes and plates (96-well) were purchased from Becton Dickinson (Franklin Lakes, NJ, USA).

Synthesis of test compounds. (2E,4E)-5-(3,4-methylenedioxyphenyl)2,4-pentadienoic acid (4-methoxyphenyl)methyl ester [1], $(2 E, 4 E)-5$ (3,4-methylenedioxyphenyl)-2,4-pentadienoic acid (4-hydroxy-3methoxyphenyl)methyl ester [2], (2E,4E)-5-(3,4-methylenedioxyphenyl)-2,4-pentadienoic acid 2-(4-hydroxyphenyl)ethyl ester [3], (2E,4E)-5-(3,4-methylenedioxyphenyl)-2,4-pentadienoic acid 2-(3,4dihydroxyphenyl)ethyl ester [4], (2E,4E)-5-(3,4-methylenedioxyphenyl)-2,4-pentadienoic acid 2-(4-methoxyphenyl)ethyl ester [5], (2E,4E)-5-(3,4-methylenedioxyphenyl)-2,4-pentadienoic acid 2-(3,4dimethoxyphenyl)ethyl ester [6], $(2 E, 4 E)-5-(3,4-m e t h y l e n e d i o x y-$ phenyl)-2,4-pentadienoic acid 2-phenylethyl ester [7], (2E,4E)-5-(3,4methylenedioxyphenyl)-2,4-pentadienoic acid 3-phenylpropyl ester [8], (2E,4E)-5-(3,4-methylenedioxyphenyl)-2,4-pentadienoic acid 4phenyl-2-butyl ester [9], (2E,4E)-5-(3,4-methylenedioxyphenyl)-2,4pentadienoic acid 4-phenylbutyl ester $[\mathbf{1 0}]$ and $(2 E, 4 E)-5-(3,4-$ methylenedioxyphenyl)-2,4-pentadienoic acid decyl ester [11] (structures shown in Figure 1) were synthesized by coupling of piperic acid with the appropriate alcohols by means of a modified procedure described elsewhere (18). To a mixture of piperic acid (1.1 mmol) and the appropriate alcohol $(1.0 \mathrm{mmol})$ in dry tetrahydrofuran $(4 \mathrm{ml})$ were added triphenylphosphine (1.5 mmol) and diisopropyl azodicarboxylate $(1.5 \mathrm{mmol})$. The reaction mixture was stirred for 2 $24 \mathrm{~h}$ at room temperature and the whole was extracted with ethyl acetate and saturated $\mathrm{NaHCO}_{3}$ solution. The organic layer was dried over $\mathrm{Na}_{2} \mathrm{SO}_{4}$ and the solvent was evaporated under reduced pressure. The residue was then purified by silica gel column chromatography to give the corresponding piperic acid ester. All compounds were dissolved in DMSO at $40 \mathrm{mM}$ and stored at $-20^{\circ} \mathrm{C}$ before use.

Cell culture. Human normal oral mesenchymal cells (human gingival fibroblast, HGF; human periodontal ligament fibroblast, HPLF; human pulp cells, HPC) were established from the first premolar tooth extracted from the lower jaw of a 12-year-old girl (19), and cells at 10-18 population doubling levels were used in this study. Human oral squamous cell carcinoma (OSCC) cell lines [Ca9-22 (derived from gingival tissue); HSC-2, HSC-3, HSC-4 (derived from tongue)] were purchased from Riken Cell Bank (Tsukuba, Japan). All of these cells were cultured at $37^{\circ} \mathrm{C}$ in DMEM<smiles>[R]O[Si](C)(C)C(=O)/C=C/C=C/c1ccc2c(c1)OCO2</smiles><smiles>COc1ccc(COS)cc1</smiles><smiles>COCCc1ccccc1</smiles><smiles>COc1cc(CO[AlH2])ccc1O</smiles><smiles>Oc1ccc(CCOS)cc1</smiles>

3<smiles>Oc1ccc(CCOS)cc1O</smiles>

4<smiles>COc1ccc(CCOS)cc1</smiles>

5<smiles>COc1ccc(CCO[As])cc1OC</smiles><smiles>CC(CCc1ccccc1)O[Hg]</smiles><smiles>COCCCCc1ccccc1</smiles>

10<smiles>CCCCCCCCCCOS</smiles>

11

supplemented with $10 \%$ heat-inactivated FBS, 100 units $/ \mathrm{ml}$, penicillin $\mathrm{G}$ and $100 \mu \mathrm{g} / \mathrm{ml}$ streptomycin sulfate under a humidified $5 \% \mathrm{CO}_{2}$ atmosphere.

Assay for cytotoxic activity. Cells were inoculated at $2.5 \times 10^{3}$ cells $/ 0.1 \mathrm{ml}$ in a 96-microwell plate. After $48 \mathrm{~h}$, the medium was replaced with $0.1 \mathrm{ml}$ of fresh medium containing different concentrations of single test compounds. Cells were incubated further for $48 \mathrm{~h}$ and the relative viable cell number was then determined by the MTT method (20). The relative viable cell number was determined by the absorbance of the cell lysate at 560 nm, using a microplate reader (Infinite F 50 R, TECAN, Kawasaki, Japan). Control cells were treated with the same amounts of DMSO 
Table I. Cytotoxic activity of 11 piperic acid esters against oral malignant and non-malignant cells. Each value represents the mean of triplicate determinations.

\begin{tabular}{|c|c|c|c|c|c|c|c|c|c|c|c|c|c|c|c|}
\hline & \multicolumn{11}{|c|}{$\mathrm{CC}_{50}(\mu \mathrm{M})$} & \multirow{2}{*}{\multicolumn{2}{|c|}{$\mathrm{TS}$}} & \multirow{2}{*}{\multicolumn{2}{|c|}{ PSE }} \\
\hline & \multicolumn{5}{|c|}{ Human oral squamous cell carcinoma cell lines } & \multicolumn{6}{|c|}{ Human normal oral cells } & & & & \\
\hline & $\begin{array}{c}\text { (A) } \\
\text { Ca9-22 }\end{array}$ & HSC-2 & HSC-3 & HSC-4 & $\begin{array}{c}(\mathrm{B}) \\
\text { mean }\end{array}$ & SD & $\begin{array}{c}\text { (C) } \\
\text { HGF }\end{array}$ & HPLF & HPC & $\begin{array}{l}(\mathrm{D}) \\
\text { mean }\end{array}$ & SD & $(\mathrm{D} / \mathrm{B})$ & $(\mathrm{C} / \mathrm{A})$ & $\begin{array}{c}\left(\mathrm{D} / \mathrm{B}^{2}\right) \\
\times 100\end{array}$ & $\begin{array}{c}\left(\mathrm{C} / \mathrm{A}^{2}\right) \\
\times 100\end{array}$ \\
\hline 1 & 26 & 44 & 40 & 41 & 38 & 8 & $>400$ & $>400$ & $>400$ & $>400$ & & $>10.5$ & $>15.1$ & $>27.8$ & $>57.2$ \\
\hline 2 & 270 & $>400$ & $>400$ & $>400$ & $>368$ & 65 & $>400$ & $>375$ & $>393$ & $>390$ & 13 & $><1.1$ & $>1.5$ & $><0.3$ & $>0.5$ \\
\hline 3 & 45 & 67 & 42 & 30 & 46 & 16 & 105 & 139 & 121 & 121 & 17 & 2.6 & 2.3 & 5.7 & 5.2 \\
\hline 4 & 5 & 28 & 22 & 13 & 17 & 10 & 118 & 151 & 138 & 136 & 17 & 8.0 & 21.6 & 47.0 & 396.0 \\
\hline 5 & 29 & 48 & 49 & 43 & 42 & 9 & 59 & 81 & 68 & 70 & 11 & 1.6 & 2.0 & 3.9 & 6.8 \\
\hline 6 & 92 & 87 & 102 & 127 & 102 & 18 & 130 & 340 & 103 & 191 & 130 & 1.9 & 1.4 & 1.8 & 1.5 \\
\hline 7 & 60 & 75 & 41 & 68 & 61 & 15 & $>400$ & $>400$ & $>400$ & $>400$ & & $>6.6$ & $>6.6$ & $>10.8$ & $>11.0$ \\
\hline 8 & $>400$ & $>400$ & $>400$ & $>400$ & $>400$ & & $>400$ & $>400$ & $>400$ & $>400$ & & $><1.0$ & $><1.0$ & $><0.3$ & $><0.3$ \\
\hline 9 & $>400$ & $>400$ & $>400$ & $>400$ & $>400$ & & $>400$ & $>400$ & $>400$ & $>400$ & & $><1.0$ & $><1.0$ & $><0.3$ & $><0.3$ \\
\hline 10 & $>400$ & $>400$ & $>400$ & $>400$ & $>400$ & & $>400$ & $>400$ & $>400$ & $>400$ & & $><1.0$ & $><1.0$ & $><0.3$ & $><0.3$ \\
\hline 11 & $>400$ & $>400$ & $>400$ & $>400$ & $>400$ & & $>400$ & $>400$ & $>400$ & $>400$ & & $><1.0$ & $><1.0$ & $><0.3$ & $><0.3$ \\
\hline DXR & 0.27 & 0.12 & 0.14 & $<0.078$ & $<0.15$ & 0.08 & $>10$ & 1.1 & 8.8 & 6.6 & 4.8 & $>43.3$ & $>37.3$ & $>28322.4$ & $>13922.9$ \\
\hline MTX & $>1000$ & 78 & 8 & 8 & $>273$ & 486 & $>1000$ & $>1000$ & $>1000$ & $>1000$ & & $><3.7$ & $><1.0$ & $><1.3$ & $><0.1$ \\
\hline
\end{tabular}

HGF: Human gingival fibroblast; HPC: human pulp cells; HPLF: human periodontal ligament fibroblast; Ca9-22 (derived from gingival tissue), HSC-2, HSC-3 and HSC-4 (derived from tongue): oral squamous cell carcinoma (OSCC) cell lines; CC $_{50}$ : 50\% cytotoxic concentration; DXR: doxorubicin; MTX: methotrexate. TS: tumor-selectivity index; PSE: potency-selectivity expression; $\mathrm{CC}_{50}: 50 \%$ cytotoxic concentration.

and the cell damage induced by DMSO was subtracted from that induced by test agents. The concentration of compound that reduced the viable cell number by $50 \%\left(\mathrm{CC}_{50}\right)$ was determined from the dose-response curve and the mean value of $\mathrm{CC}_{50}$ for each cell type was calculated from triplicate assays. Changes in cell morphology were observed under the light microscope (EVOSfl, ThermoFisher Scientific, Waltham, Mass, USA).

Calculation of tumor-selectivity index (TS). TS was calculated using the following equation: $\mathrm{TS}=$ mean $\mathrm{CC}_{50}$ against three normal cells/mean $\mathrm{CC}_{50}$ against for OSCC cell lines [(D/B) in Table I]. Since both Ca9-22 and HGF cells were derived from the gingival tissue (21), the relative sensitivity of these cells was also compared [(C/A) in Table I]. We did not use human normal oral keratinocytes as controls, since many anticancer drugs showed potent cytotoxicity against normal keratinocytes by inducing apoptosis (20).

Calculation of potency-selectivity expression (PSE). PSE was calculated using the following equation: $\mathrm{PSE}=\mathrm{TS} / \mathrm{CC}_{50}$ against tumor cells $\times 100$ (22) [that is, (D/B $\left.{ }^{2}\right) \times 100$ (HGF, HPLF, HPC vs. Ca9-22, HSC-2, HSC3 , HSC-4) and $\left(\mathrm{C} / \mathrm{A}^{2}\right) \times 100(\mathrm{HGF}$ vs $\mathrm{Ca} 9-22)$ in Table I].

Estimation of $\mathrm{CC}_{50}$ values. Since the $\mathrm{CC}_{50}$ values had a distribution pattern close to a logarithmic normal distribution, we used the $\mathrm{pCC}_{50}$ (i.e., the $-\log \mathrm{CC}_{50}$ ) for the comparison of the cytotoxicity between the compounds. The mean $\mathrm{pCC}_{50}$ values for normal cells and tumor cell lines were defined as $\mathrm{N}$ and T, respectively (22).

Calculation of chemical descriptors. The 3D-structure of each chemical structure (drawn by Marvin Sketch ver 16, ChemAxon, Budapest, Hungary, http://www.chemaxon.com) was optimized by
Table II. Anti-HIV activity of piperic acid esters and chemotherapeutic agents. Each value represents the mean of triplicate determinations.

\begin{tabular}{lccc}
\hline Piperic acid esters & $\mathrm{CC}_{50}(\mu \mathrm{M})$ & $\mathrm{EC}_{50}(\mu \mathrm{M})$ & $\begin{array}{c}\text { Anti-HIV activity } \\
\mathrm{SI}\left(=\mathrm{CC}_{50} / \mathrm{EC}_{50}\right)\end{array}$ \\
\hline $\mathbf{1}$ & 266 & $>400$ & $<1$ \\
$\mathbf{2}$ & 322 & $>400$ & $<1$ \\
$\mathbf{3}$ & 119 & $>400$ & $<1$ \\
$\mathbf{4}$ & $>400$ & $>400$ & $><1$ \\
$\mathbf{5}$ & $>400$ & $>400$ & $><1$ \\
$\mathbf{6}$ & 137 & $>400$ & $<1$ \\
$\mathbf{7}$ & $>400$ & $>400$ & $><1$ \\
$\mathbf{8}$ & 390 & $>400$ & $<1$ \\
$\mathbf{9}$ & $>400$ & $>400$ & $><1$ \\
$\mathbf{1 0}$ & $>400$ & $>400$ & $><1$ \\
$\mathbf{1 1}$ & $>400$ & $>400$ & $><1$ \\
Positive controls & & & \\
Dextran sulfate $(\mu \mathrm{g} / \mathrm{ml})$ & 233 & 0.777 & 300 \\
Curdlan sulfate $(\mu \mathrm{g} / \mathrm{ml})$ & $>1000$ & 0.172 & $>5805$ \\
Azidothymidine & 53 & 0.026 & 2017 \\
2',3'-Dideoxycytidine & 1859 & 1.113 & 1670 \\
\hline
\end{tabular}

$\mathrm{CC}_{50}: 50 \%$ Cytotoxic concentration; $\mathrm{EC}_{50}: 50 \%$ effective concentration; SI: selectivity index $\left(\mathrm{CC}_{50} / \mathrm{EC}_{50}\right)$.

CORINA Classic (Molecular Networks GmbH, Germany) and force-field calculations (amber-10: EHT) in Molecular Operating Environment (MOE) version 2015.1001 (Chemical Computing Group Inc., Quebec, Canada). The number of structural descriptors 


\section{A}
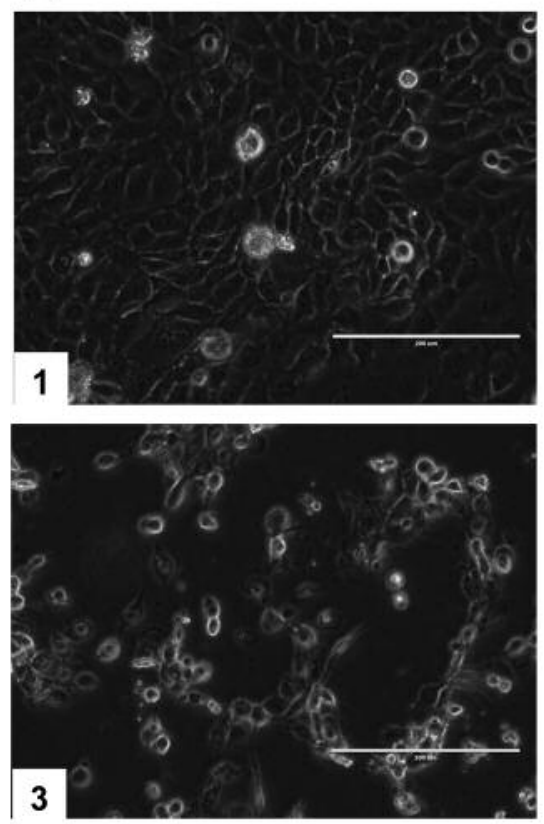
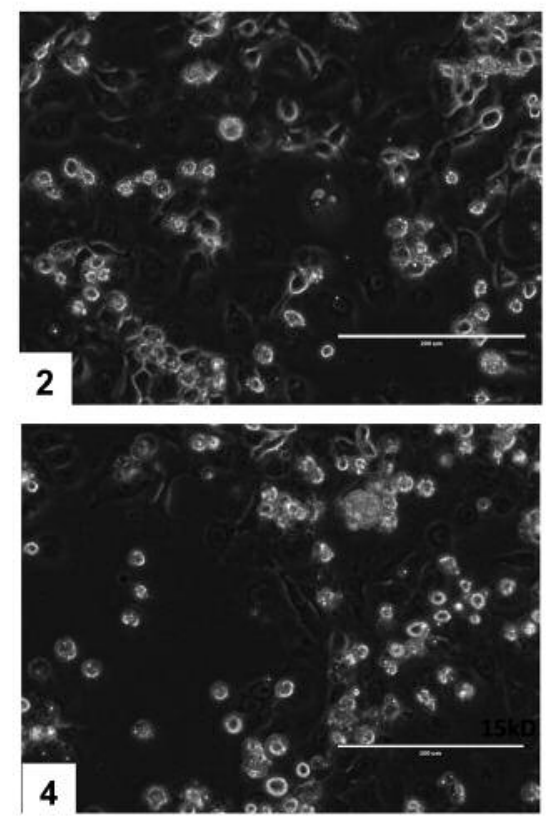

B

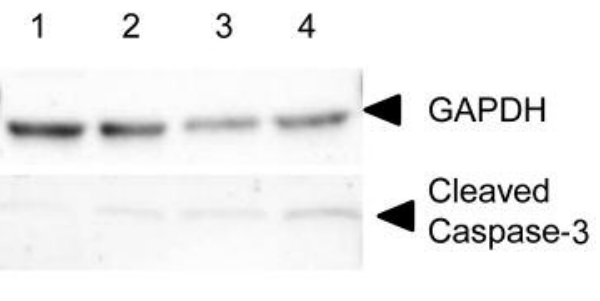

1. Control (0.2\%DMSO)

2. $20 \mu \mathrm{M}[4]$

3. $80 \mu \mathrm{M}[4]$

4. Actinomycin $\mathrm{D}(1 \mu \mathrm{M})$

Figure 2. Apoptosis induction by [4] in HSC-2 human oral squamous cell carcinoma cell line. Bars in A, 200 um.

calculated from MOE and Dragon 7.0 (Kode srl., Pisa, Italy) after the elimination of overlapped descriptors were 302 and 2747 , respectively.

The following 15 Dragon descriptors and 2 MOE descriptors were significantly correlated with $\mathrm{T}, \mathrm{N}$ and T-N.

Dragon descriptors (23): CATS2D_04_AL (CATS2D AcceptorLipophilic at lag 04), CATS3D_13_AL (CATS3D AcceptorLipophilic BIN 13), CATS3D_16_AA (CATS3D Acceptor-Acceptor BIN 16), CATS3D_17_AA (CATS3D Acceptor-Acceptor BIN 17), Dp (D total accessibility index/weighted by polarizability), HATS5i (leverage-weighted autocorrelation of lag $5 /$ weighted by ionization potential), JGI10 (mean topological charge index of order 10), MATS5v (Moran autocorrelation of lag 5 weighted by van der Waals volume), $\mathrm{R} 2 \mathrm{e}+$ ( $\mathrm{R}$ maximal autocorrelation of lag 2/weighted by Sanderson electronegativity), R5i+ (R maximal autocorrelation of lag 5/weighted by ionization potential), $R 5 u+(R$ maximal autocorrelation of lag 5/unweighted), SPH (spherosity), TDB08e (3D Topological distance based descriptors - lag 8 weighted by Sanderson electronegativity, TDB08i (3D Topological distance based descriptors - lag 8 weighted by ionization potential), and TDB08u (3D Topological distance based descriptors - lag 8 unweighted).

MOE descriptors: rsynth (the synthetic reasonableness, or feasibility, of the chemical structure), and vsurf_DW13 (Contact distances of vsurf_Ewmin 13; Surface Area, Volume and Shape Descriptor. The vsurf_ descriptors are similar to the VolSurf descriptors (24).

Western blot analysis. The cells were washed with PBS and processed for western blot analysis, as described previously (22).
Antibodies against cleaved caspase-3 (Cell Signaling Technology Inc., Beverly, MP, USA) and glyceraldehyde 3-phosphate dehydrogenase (GAPDH; Trevigen, Gaithersburg, MD, USA) were used as primary antibodies. As secondary antibodies, we used $\alpha$ rabbit IgG (DAKO, Tokyo, Japan) antibodies which were conjugated with horseradish peroxidase.

Assay for anti-HIV activity. HTLV-I-carrying human T-cell line MT4 cells, highly sensitive to human immunodeficiency virus-1 (HIV1), were infected with HIV-1 ${ }_{\text {IIIB }}$ at a multiplicity of infection of 0.01. HIV- and mock-infected (control) MT-4 cells were incubated for 5 days with different concentrations of samples and the relative viable cell number was determined by the MTT assay. The $\mathrm{CC}_{50}$ and $50 \%$ effective concentration $\left(\mathrm{EC}_{50}\right)$ were determined from the dose-response curve for mock-infected and HIV-infected cells, respectively (25). All data represent the mean values of triplicate measurements. The anti-HIV activity was evaluated by selectivity index (SI) $\left(=\mathrm{CC}_{50} / \mathrm{EC}_{50}\right)$.

Statistical treatment. The relation among cytotoxicity, tumor specificity index and chemical descriptors was investigated using simple regression analyses by JMP Pro version 12.2.0 (SAS Institute Inc., Cary, NC, USA). The significance level was set at $p<0.05$.

\section{Results}

Cytotoxicity. Among eleven piperic acid ester derivatives, 2(3,4-dihydroxyphenyl)ethyl ester [4] showed the highest cytotoxicity against OSCC cell lines (mean $\mathrm{CC}_{50}=17 \mu \mathrm{M}$ ), 

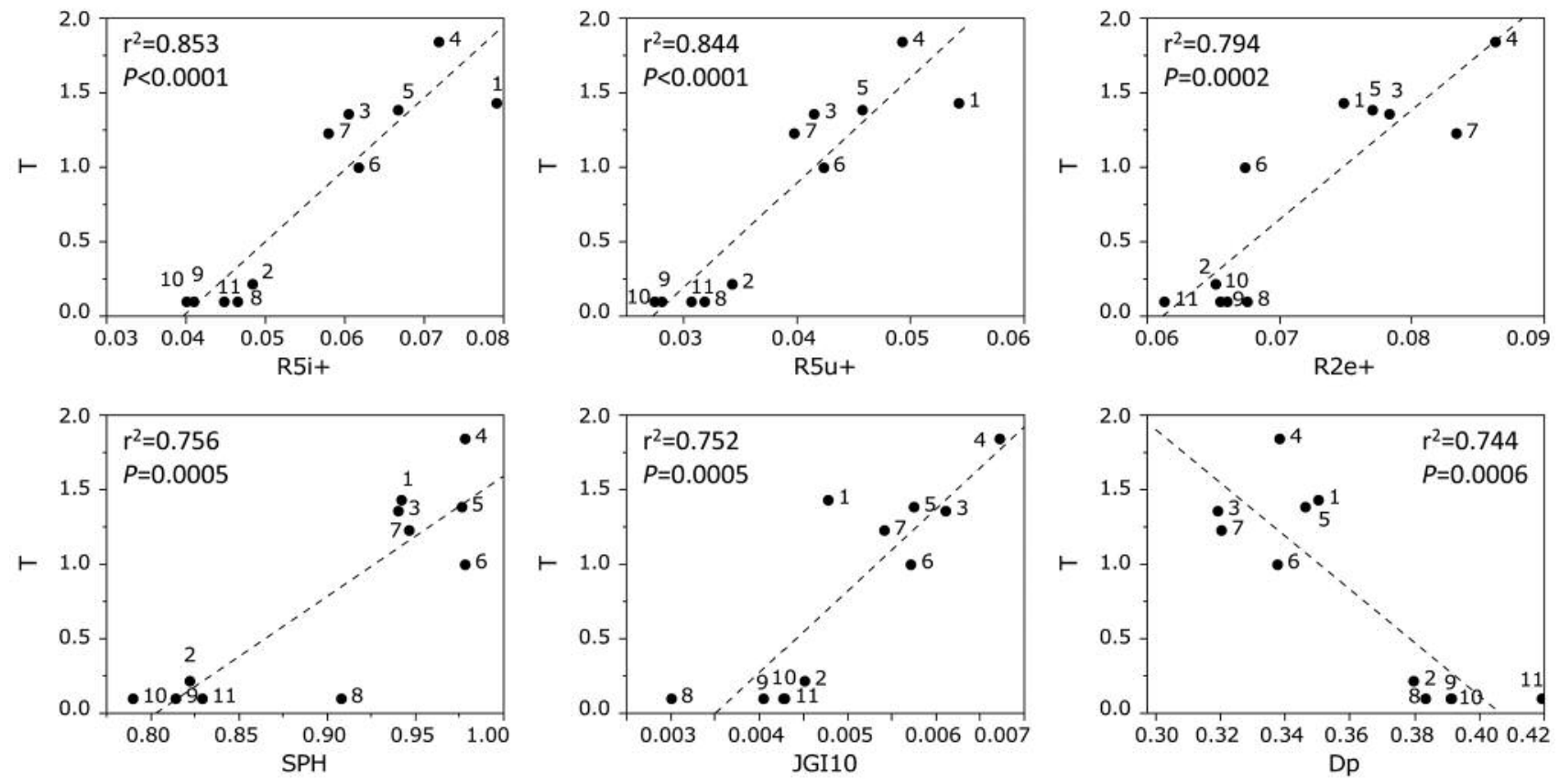

Figure 3. Determination of coefficient between chemical descriptors and cytotoxicity of piperic acid esters against tumor cells (defined as T). The mean $\left(p C C_{50}\right.$ i.e., the $\left.-\log C C_{50}\right)$ values for tumor cell lines were defined as $T$.

followed by (4-methoxyphenyl)methyl ester (38 $\mu \mathrm{M})$ [1], 2(4-methoxyphenyl)ethyl ester [5] (42 $\mu \mathrm{M})$, 2-(4hydroxyphenyl)ethyl ester (46 $\mu \mathrm{M})$ [3], 2-phenylethyl ester [7] $(61 \mu \mathrm{M})$ and 2-(3,4-dimethoxyphenyl)ethyl ester [6] (102 $\mu \mathrm{M})$. On the other hand, (4-hydroxy-3-methoxyphenyl)methyl ester [2] (>368 $\mu \mathrm{M})$, 3-phenylpropyl ester [8], 4-phenyl-2-butyl ester [9], 4-phenylbutyl ester [10] and decyl ester [11] $(>400 \mu \mathrm{M})$ were essentially inactive (Table I).

Tumor-specificity. When four OSCC cell lines and three normal oral cells were used, [1] showed the highest TS value (>10.5), followed by [4] (8.0), [7] (>6.6), [3] (2.6), [6] (1.9), [5] (1.6), [2] $(><1.1)$ and $[8,9,10,11](><1.0)(\mathrm{D} / \mathrm{B}$ in Table I). [4] showed the highest PSE value (47.0), followed by [1] $(>27.8),[7](>10.8),[3](5.7),[5](3.9),[6](1.8)$, and [2, 8, 9, 10, 11] $(><0.3)\left(\mathrm{D} / \mathrm{B}^{2} \times 100\right.$ in Table I).

When Ca9-22 and HGF cells, both derived from gingival tissue, were used, [4] showed the highest TS value (21.6), followed by [1] (>15.1), [7] (>6.6), [3] (2.3), [5] (2.0), [2] $(>1.5),[6](1.4)$ and $[\mathbf{8 , 9}, \mathbf{1 0}, \mathbf{1 1}](><1.0)(\mathrm{C} / \mathrm{A}$ in Table I). [4] showed the highest PSE value (396.0), followed by [1] (>57.2), [7] (>11.0), [5] (6.8), [3] (5.2), [6] (1.5), [2] (>0.5) and $[8,9,10,11](><0.3)\left(C / \mathrm{A}^{2} \times 100\right.$ in Table I).

Treatment with HSC-2 cells with [4] induced cell shrinkage (A) and stimulated the cleavage of caspase-3 (B), suggesting the induction of apoptosis (Figure 2).
Anti-HIV activity of chalcones. In contrast to popular antiHIV agents (dextran sulfate, curdlan sulfate, azidothymidine, 2',3'-dideoxycytidine) ( $\mathrm{SI}=300-5805)$, none of the piperic esters protected cells from the cytopathic effect of HIV infection $(\mathrm{SI}<1)$ (Table II). Based on these data, the subsequent QSAR analysis was focused on the cytotoxicity of piperic acid esters.

Computational analysis. We next performed the QSAR analysis of piperic acid esters in regards to their cytotoxicity against tumor cells and normal cells. Among a total of 3049 descriptors, 17 descriptors described below correlated well with cytotoxicity and tumor specificity.

Cytotoxicity of piperic acid esters against human OSCC cell lines was correlated with R5i+ (molecular shape and ionization potential) $\left(\mathrm{r}^{2}=0.853, p<0.0001\right), \mathrm{R} 5 \mathrm{u}+$ (molecular shape) $\left(\mathrm{r}^{2}=0.844, p<0.0001\right), \mathrm{R} 2 \mathrm{e}+($ molecular shape and electronegativity) $\left(\mathrm{r}^{2}=0.794, p=0.0002\right), \mathrm{SPH}$ (molecular spherosity) $\left(\mathrm{r}^{2}=0.756, p=0.0005\right), \mathrm{JGI} 10$ (topological charge) $\left(\mathrm{r}^{2}=0.752, \quad p=0.0005\right), \quad \mathrm{Dp} \quad$ (molecular shape and polarizability) $\left(\mathrm{r}^{2}=0.744, p=0.0006\right)$ (Figure 3$)$.

Cytotoxicity of piperic acid esters against human normal oral mesenchymal cells was correlated with CATS3D_17_AA (molecular shape and H-bond acceptor) $\left(\mathrm{r}^{2}=0.957, p<0.0001\right)$, rsynth (synthetic feasibility) $\left(\mathrm{r}^{2}=0.942, \quad p<0.0001\right)$, 

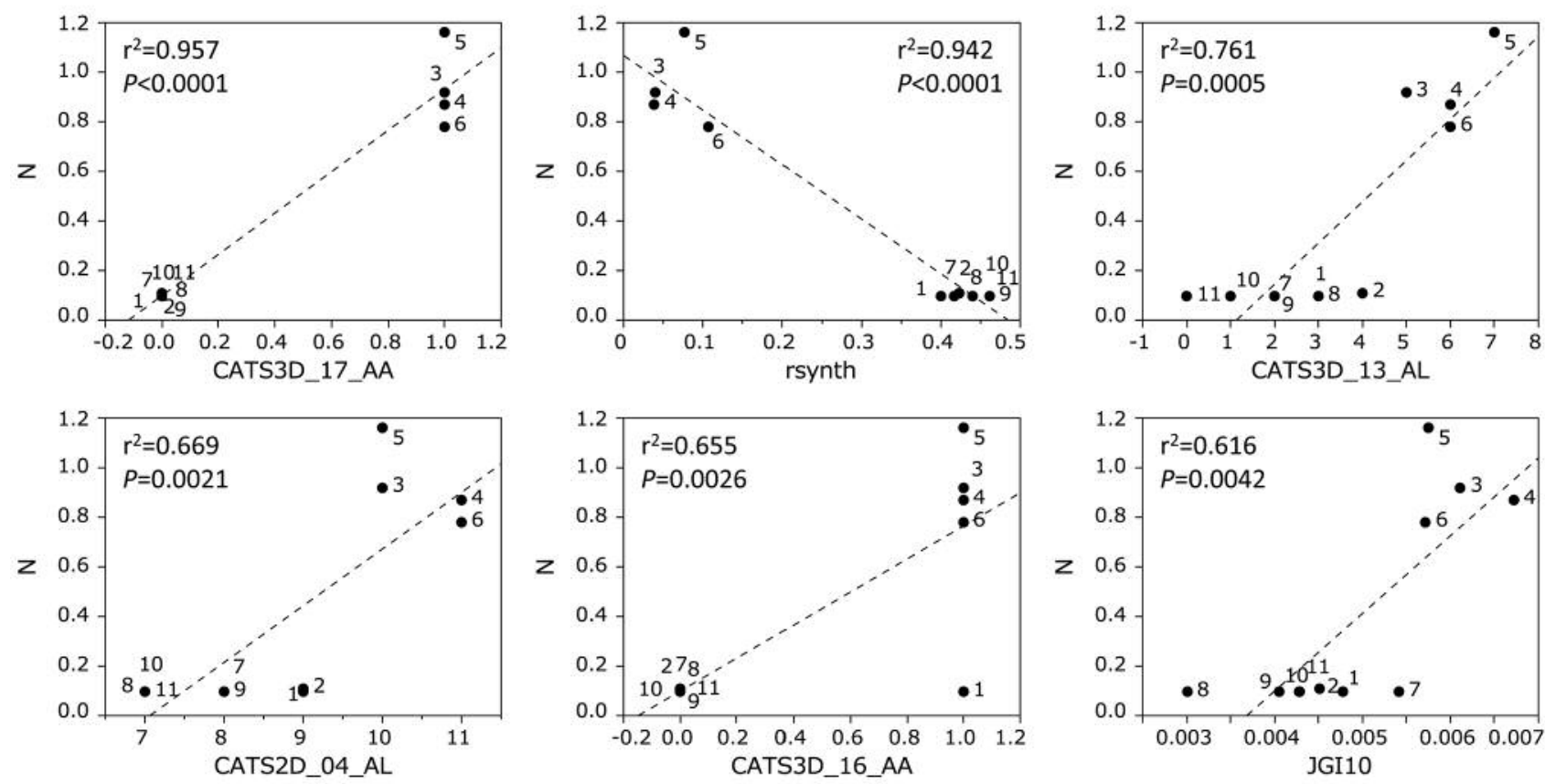

Figure 4. Determination of coefficient between chemical descriptors and cytotoxicity of piperic acid esters against normal cells (defined as $N$ ). The mean ( $p C C_{50}$ i.e., the $-\log C C_{50}$ ) values for normal cells were defined as $N$.

CATS3D_13_AL (molecular shape, H-bond acceptor and lipophilicity $) \quad\left(\mathrm{r}^{2}=0.761, \quad p=0.0005\right), \quad$ CATS2D_04_AL (topological shape, H-bond acceptor and lipophilicity) $\left(\mathrm{r}^{2}=0.669, p=0.0021\right)$, CATS3D_16_AA (molecular shape and H-bond acceptor) $\left(\mathrm{r}^{2}=0.655, p=0.0026\right)$, JGI10 (topological charge) $\left(\mathrm{r}^{2}=0.616, p=0.0042\right)$ (Figure 4$)$.

Tumor specificity of piperic acid esters was correlated with vsurf_DW13 (molecular size and shape) $\left(\mathrm{r}^{2}=0.668, p=0.0021\right)$, HATS5i (topological shape and ionization potential) $\left(\mathrm{r}^{2}=0.659\right.$, $p=0.0024)$, TDB08u (molecular shape) $\left(\mathrm{r}^{2}=0.658, p=0.0024\right)$, TDB08i (molecular shape and ionization potential) $\left(\mathrm{r}^{2}=0.653\right.$, $p=0.0026$ ), TDB08e (molecular shape and electronegativity) $\left(\mathrm{r}^{2}=0.653, p=0.0026\right)$, MATS5v (topological shape and molecular size) $\left(\mathrm{r}^{2}=0.646, p=0.0029\right)$ (Figure 5).

\section{Discussion}

We have synthesized eleven piperic acid esters, of which ten compounds except [11] are new compounds. The present study demonstrated that five phenylethyl esters $[\mathbf{3}, \mathbf{4 , 5}, \mathbf{6}$, 7] showed relatively higher cytotoxicity and tumor specificity, without or with the introduction of hydroxyl group or methoxy group in the benzene ring. Phenymethyl ester [1] also showed higher tumor-specificity, but removal of the methoxy group [2] resulted in significant reduction in both cytotoxicity and tumor-specificity. On the other hand, compounds with longer side chains such as phenylpropyl ester $[\mathbf{8}]$, phenylbutyl ester $[\mathbf{9 , 1 0}$ and decyl ester $[\mathbf{1 1}]$ were essentially inactive (Table I).

Among the 11 compounds, [4] had the highest TS $(\mathrm{D} / \mathrm{B}=8.0, \mathrm{C} / \mathrm{A}=21.6)$ and $\mathrm{PSE}$ values $\left(\mathrm{D} / \mathrm{B}^{2} \times 100=47.0, \mathrm{C} / \mathrm{A}^{2}\right.$ $\times 100=396.0$ ) (Table I). It should be noted that TS/PSE values of [4] were higher than those of methotrexate (TS $=><1.0 \sim 3.7$, $\mathrm{PSE}=><0.1 \sim 1.3)$, albeit much lower than those of doxorubicin $(\mathrm{TS}=>3.7 .3 \sim 43.3, \quad \mathrm{PSE}=>12922.9 \sim 28322.4) \quad$ (Table I). Apoptosis-inducing activity of [4] further suggests its antitumor potential.

QSAR analysis demonstrated that tumor specificity of piperic acid esters was rather correlated with vsurf_DW13, HATS5i, TDB08u, TDB08i, TDB08e and MATS5v that reflects molecular size, ionization potential, molecular shape, ionization potential, electronegativity, and molecular size, respectively (Figure 5). However, chemical descriptors that were correlated with cytotoxicity against normal cells (CATS3D_17_AA, rsynth, CATS3D_13_AL, CATS2D_04_ AL, CATS3D_16_AA and JGI10) (Figure 3) and tumor cells (R5i+, R5u+, R2e+, SPH, JGI10, DP) were quite different with each other. This suggests that modification of backbone structure of piperic acid esters can produce more selective compounds.

The present study demonstrated that eleven piperic acid esters had no ant-HIV activity. We reported previously that 

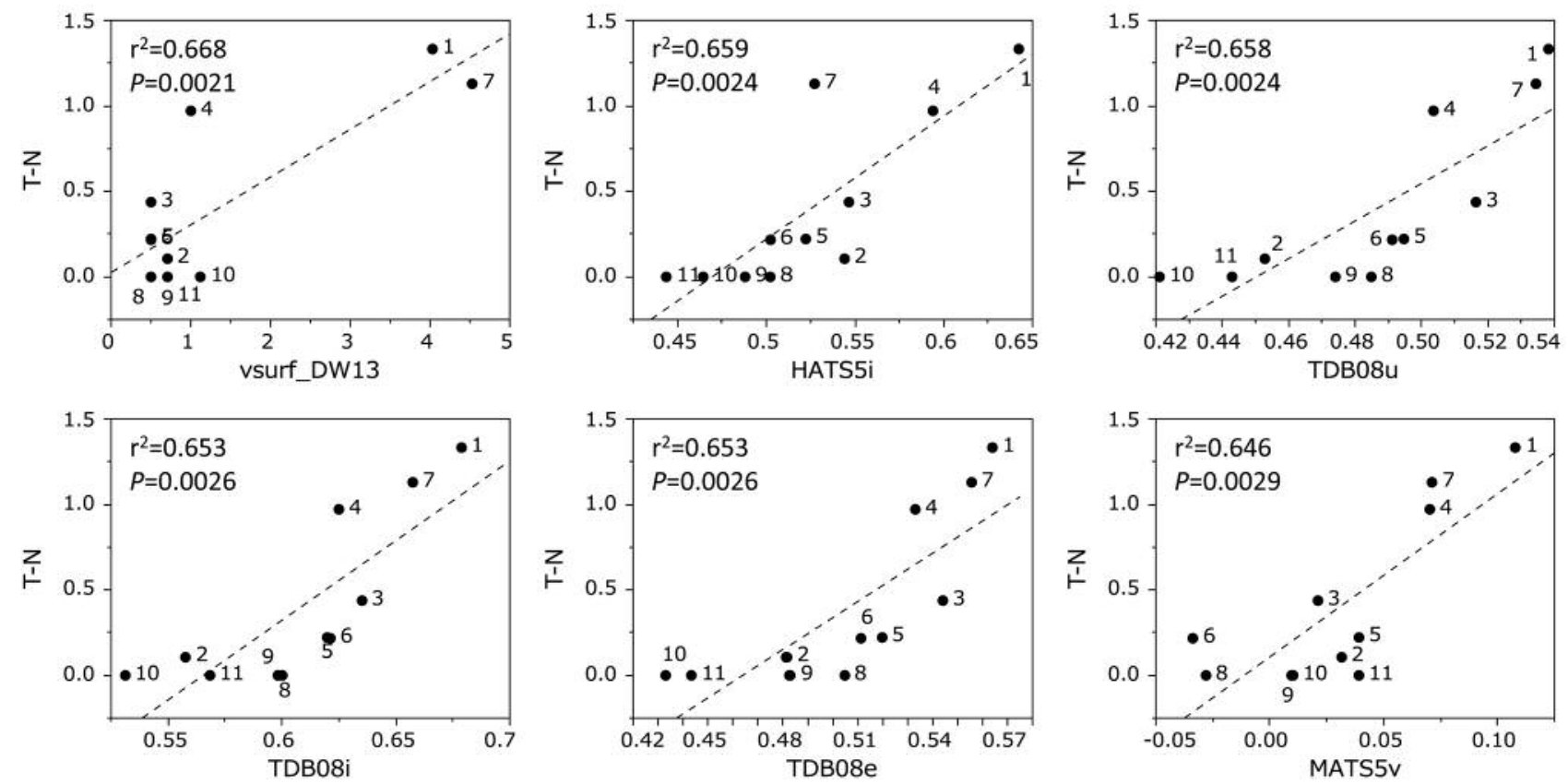

Figure 5. Determination of coefficient between chemical descriptors and tumor specificity of piperic acid esters (defined as $T-N)$.

twelve piperic acid amides had no anti-HIV activity, in agreement with the absence of publication regarding the antiviral activity of piperic acid esters on pubmed search.

In conclusion, compound $\mathbf{4}$ is a potential lead compound for synthesizing more potent compounds targeted against OSCC cells.

\section{Conflicts of Interest}

The Authors wish to confirm that there are no known conflicts of interest associated with this publication and there has been no significant financial support for this work that could have influenced its outcome.

\section{Acknowledgements}

This work was partially supported by KAKENHI from the Japan Society for the Promotion of Science (JSPS) (15K08111, 16K11519). The annual license of the statistical software, JMP Pro, was supported by the grant-in-aid of the oncology specialist's promotion program by the Ministry of Education, Culture, Sports, Science and Technology, Japan.

\section{References}

1 Butt MS, Pasha I, Sultan MT, Randhawa MA, Saeed F and Ahmed W: Black pepper and health claims: a comprehensive treatise. Crit Rev Food Sci Nutr 53(9): 875-886, 2013.
2 Bhardwaj RK, Glaeser H, Becquemont L, Klotz U, Gupta SK and Fromm MF: Piperine, a major constituent of black pepper, inhibits human P-glycoprotein and CYP3A4. J Pharmacol Exp Ther 302(2): 645-650, 2002.

3 Najar IA, Sharma SC, Singh GD, Koul S, Gupta PN, Javed S and Johri RK: Involvement of P-glycoprotein and CYP 3A4 in the enhancement of etoposide bioavailability by a piperine analogue. Chem Biol Interact 190(2-3): 84-90, 2011.

4 Sharma S, Kumar M, Sharma S, Nargotra A, Koul S and Khan IA: Piperine as an inhibitor of Rv1258c, a putative multidrug efflux pump of Mycobacterium tuberculosis. J Antimicrob Chemother 65(8): 1694-1701, 2010.

5 Das B, Kundu J, Bachar SC, Uddin MA and Kundu JK: Antitumor and antibacterial activity of ethylacetate extract of Ludwigia hyssopifolia Linn and its active principle piperine. Pak J Pharm Sci 20(2): 128-131, 2007.

6 Wattanathorna J, Chonpathompikunlertb P, Muchimapuraa S, Pripremc A and Tankamnerdthai O: Piperine, the potential functional food for mood and cognitive disorders. Food Chem Toxicol 46(9): 3106-3110, 2008.

7 Bang JS, Oh DH, Choi HM, Sur BJ, Lim SJ, Kim JY, Yang HI, Yoo MC, Hahm DH and Kim KS: Anti-inflammatory and antiarthritic effects of piperine in human interleukin $1 \beta$ stimulated fibroblast-like synoviocytes and in rat arthritis models. Arthritis Res Ther 11(2): R49, 2009.

8 Doucette CD, Hilchie AL, Liwski R and Hoskin DW: Piperine, a dietary phytochemical, inhibits angiogenesis. J Nutr Biochem 24: 231-239, 2013.

9 Yaffe PB, Power Coombs MR, Doucette CD, Walsh M and Hoskin DW: Piperine, an alkaloid from black pepper, inhibits 
growth of human colon cancer cells via G1 arrest and apoptosis triggered by endoplasmic reticulum stress. Mol Carcinog, 54(10): 1070-1085, 2015.

10 Fofaria NM, Kim SH and Srivastava SK: Piperine causes G1 phase cell-cycle arrest and apoptosis in melanoma cells through checkpoint kinase-1 activation. PLoS One 9(5): e94298, 2014.

11 Lin Y, Xu J, Liao H, Li L and Pan L: Piperine induces apoptosis of lung cancer A549 cells via p53-dependent mitochondrial signaling pathway. Tumour Biol 35(4): 3305-3310, 2014.

12 Yaffe PB, Doucette CD, Walsh M and Hoskin DW: Piperine impairs cell cycle progression and causes reactive oxygen species-dependent apoptosis in rectal cancer cells. Exp Mol Pathol 94(1): 109-114, 2013.

13 Ouyang DY, Zeng LH, Pan H, Xu LH, Wang Y, Liu KP and He $\mathrm{XH}$ : Piperine inhibits the proliferation of human prostate cancer cells via induction of cell-cycle arrest and autophagy. Food Chem Toxicol 60: 424-430, 2013.

14 Pathak N and Khandelwal S: Cytoprotective and immunomodulating properties of piperine on murine splenocytes: an in vitro study. Eur J Pharmacol 576(1-3): 160-170, 2007.

15 Choi BM, Kim SM, Park TK, Li G, Hong SJ, Park R, Chung HT and Kim BR: Piperine protects cisplatin-induced apoptosis via heme oxygenase-1 induction in auditory cells. J Nutr Biochem 18(9): 615-622, 2007.

$16 \mathrm{Fu}$ M, Sun ZH and Zuo HC: Neuroprotective effect of piperine on primarily cultured hippocampal neurons. Biol Pharm Bull 33(4): 598-603, 2010.

17 Shimada C, Uesawa Y, Ishihara M, Kagaya H, Kanamto T, Terakubo S, Nakashima H, Takao K, Miyashiro T, Sugita Y and Sakagami H: Quantitative structure-cytotoxicity relationship of piperic acid amides. Anticancer Res 34(9): 4877-4884, 2014.

18 Chapado L, Linares-Palomino PJ, Salido S, Altarejos J, Rosado JA and Salido GM: Synthesis and evaluation of the platelet antiaggregant properties of phenolic antioxidants structurally related to rosmarinic acid. Bioorg chem 38: 108-114, 2010.
19 Kantoh K, Ono M, Nakamura Y, Nakamura Y, Hashimoto K, Sakagami $\mathrm{H}$ and Wakabayashi $\mathrm{H}$ : Hormetic and anti-radiation effects of tropolone-related compounds. In Vivo 24: 843-852, 2010.

20 Sakagami H, Okudaira N, Masuda Y, Amano O, Yokose S, Kanda Y, Suguro M, Natori T, Oizumi $H$ and Oizumi $T$ : Induction of Apoptosis in human oral keratinocyte by doxorubicin. Anticancer Res 37(3): 1023-1029, 2017.

21 Horikoshi M, Kimura Y, Nagura H, Ono T and Ito H: A new human cell line derived from human carcinoma of the gingiva. I. Its establishment and morphological studies. Jpn J Oral Maxillofac Surg 20: 100-106, 1974.

22 Sakagami H, Masuda Y, Tomomura M, Yokose S, Uesawa Y, Ikezoe N, Asahara D, Takao K, Kanamoto T, Terakubo S, Kagaya $\mathrm{H}$, Nakashima H and Sugita Y: Quantitative structure-cytotoxicity relationship of chalcones. Anticancer Res 37: 1091-1098, 2017.

23 "Calculate Descriptors", MOE2015.10 on-line help manual, Chemical Computing Group.

24 Cruciani G, Crivori P, Carrupt P-A and Testa B: Molecular fields in quantitative structure-permeation relationships: the VolSurf Approach. J Mol Struct 503(1-2): 17-30, 2000.

25 Nakashima H, Murakami T, Yamamoto N, Sakagami H, Tanuma $\mathrm{S}$, Hatano T, Yoshida T and Okuda T: Inhibition of human immunodeficiency viral replication by tannins and related compounds. Antiviral Res 18: 91-103, 1992.
Received August 21, 2017

Revised September 7, 2017

Accepted September 8, 2017 